\title{
Qualitative and Quantitative Analysis of Organic Acid Production Influenced by Phosphate Sources under Submerged Culture of Aspergillus niger a Phosphate Solubilising Fungi
}

\author{
Hruda Ranjan Sahoo and Nibha Gupta*
}

Division of Plant Pathology and Microbiology, Regional Plant Resource Centre, Bhubaneswar-751015, Odisha, India

*Corresponding author

\begin{tabular}{|c|c|}
\hline & A B S T R A C T \\
\hline Keywords & \multirow{9}{*}{$\begin{array}{l}\text { Aspergillus niger inoculated into medium containing Tricalcium phosphate (TCP) } \\
\text { and Rock phosphate (RP) resulted in acid production which is indicated from the } \\
\text { measure of pH and titrable acidity. Maximum of } 105 \mathrm{mM} \text { acid production is } \\
\text { recorded in TCP supplemented culture of } 12 \text { days whereas it is } 124 \mathrm{mM} \text { in nutrient } \\
\text { medium aided with RP and } 14 \text { days old culture. At the same time, decline of pH } \\
\text { has also been observed in media containing TCP and RP. However, fungal } \\
\text { biomass did not show any impact of both the kind of P sources. Chromatographic } \\
\text { analysis of culture filtrate has showed the presence of citric and oxalic acid in TCP } \\
\text { and RP respectively. Cultural conditions of different range of pH and incubation } \\
\text { temperature do not play an important role in organic acid secretion by the fungi } \\
\text { but organic acid secretion is mostly influenced by the nutritional sources such as } \\
\text { carbon and nitrogenous compounds present in the medium. }\end{array}$} \\
\hline Aspergillus niger, & \\
\hline & \\
\hline Phosphate, & \\
\hline $\begin{array}{l}\text { Rock Phosphate, } \\
\text { Organic acid. }\end{array}$ & \\
\hline Artic & \\
\hline $\begin{array}{l}\text { Accepted: } \\
\text { 10 July } 2017\end{array}$ & \\
\hline $\begin{array}{l}\text { Available Online: } \\
\text { 10 September } 2017\end{array}$ & \\
\hline & \\
\hline
\end{tabular}

\section{Introduction}

Organic acids are the source of biotical generated $\mathrm{H}^{+}$ions, which can mineralize bound phosphate present in soil and make it available for the uptake by plants (Bhattacharya and Jain, 2000). The organic acid concentration in soil solution is typically low, varying from 1 to $50 \mathrm{mM}$ (Strobel, 2001). Hence, microbial production of low molecular weight organic acids enhances mobilisation of phosphate compounds (Bolan et al., 1994; Goldstein, 1995) which is also accompanied by acidification of the medium. Organic acids such as acetate, citrate, gluconate, lactate, malate, oxalate, succinate etc. can form complexes with the metals such as aluminium, calcium, and iron releasing phosphate into soil from respective metal phosphates andcan also increase $\mathrm{P}$ availability by blocking $\mathrm{P}$ adsorption sites on soil particles (Jones, 1998; Rodriguez and Fraga, 1999; Gyaneswar et al., 2002). It is observed that tri- and dicarboxylic acids are more effective in solubilising $\mathrm{P}$ as compared to monobasic and aromatic acids-aliphatic acids (Mahidi et al., 2011).The solubilization of different sources of $\mathrm{P}$ does not depend only on the total amount of acids produced but also on type of acid produced (Cunningham and 
Kuiack, 1992, Kang et al., 2002). However, organic acid production is also influenced by the micro-organism and $\mathrm{P}$ source where it grows (Scervino et al., 2010). The type of organic acid produced and their amounts may also differ with different organisms. A number of factors have been considered as they also affect the organic acid production with $\mathrm{pH}$ lowering by microorganisms, such as the C and N sources (Di Simine et al., 1998; Reyes et al., 1999).

Aspergillus niger is a fungus which is known to solubilise inorganic phosphate such as calcium and aluminium phosphates (Illmer et al., 1995; Barroso and Nahas; 2005) through production of organic acids such as citric, gluconic, succinic and oxalic acid along with drop in $\mathrm{pH}$ of the medium (Nahas et al., 1990; Illmer and Schinner, 1995). Studies by Venketeswarlu et al., 1984 reported lactic acid as only acid produced by $A$. niger while Vazquez et al., 2000 reported succinic acid as the only acid produced by A. niger. Reports also reveal that carbon as well as nitrogen sources and $\mathrm{pH}$ of the medium greatly influence organic acid production (Gupta et al., 1976).

In the present study, we have conducted experiments to observe the organic acid production at periodic intervals when the organism A. niger is inoculated with different phosphate sources such as Tricalcium phosphate and rock phosphate as well as on modification of culture conditions such as temperature, $\mathrm{pH}$ and nutritional parameters such as carbon and nitrogen sources in presence of TCP and rock phosphate.

\section{Materials and Methods}

Modified Czapekdox medium containing Tricalcium phosphate $(\mathrm{pH}$ 6.8) and rock phosphate $(\mathrm{pH}$ 7.2) were inoculated with equal amount of inoculum of Aspergillus niger and incubated at $28^{\circ} \mathrm{C}$ for a period of 2 weeks. At a regular interval of 48 hours from period of incubation, flasks proliferated by the organism were analysed for their $\mathrm{pH}$ and titrable acidity. The $\mathrm{pH}$ change of the culture medium was recorded with the help of $\mathrm{pH}$ meter. Titrable acidity (TA) was estimated using or titrating $1 \mathrm{ml}$ of culture supernatant against $10 \mathrm{mM} \mathrm{NaOH}$ in presence of phenolphthalein indicator at regular interval (Whitelaw et al., 1999). The biomass obtained was air dried and weighed.

The culture supernatant obtained was concentrated and spotted on the chromatographic paper along with the standards of organic acids. The chromatogram was run in pre saturated chamber containing solvent mixture of n-butanol, acetic acid and water in the ratio 12:3:5. The chromatogram was air dried and sprayed with bromocresol green. After air dried the $\mathrm{Rf}$ values of the yellow spots of organic acids developed on blue background was measured and compared with $\mathrm{Rf}$ values of standard organic acid for identification.

The same Czapekdox Medium was prepared with further modification of carbon and nitrogen sources (nutritional parameters) and $\mathrm{pH}$ and temperature (Cultural parameters) for estimation of titrable acidity and recording of $\mathrm{pH}$ after completion of incubation period.For studies with nutritional modification, the carbon sources such as Fructose, Glucose, Inositol, Lactose, Maltose, Mannose, Raffinose, Sorbose and sucrose were taken in the medium and $\mathrm{pH}$ maintained at 7 and temperature $28^{\circ} \mathrm{C}$. Likewise, nitrogen sources such as Ammonium chloride, Ammonium Sulphate, L-Glutamine, L-Phenylalanine, LThreonine, L-valine, Potassium nitrate, Urea and Sodium nitratewere taken in the medium and $\mathrm{pH}$ maintained at 7 and temperature $28^{\circ} \mathrm{C}$. Similarly for studies with cultural modifications, the $\mathrm{pH}$ of the medium was 
modified in the range of 5-9 and incubated at constant temperature of $28^{\circ} \mathrm{C}$. The incubation temperature was modified in the range of 20$40^{\circ} \mathrm{C}$ with $\mathrm{pH}$ of the medium at 7 . The amount of organic acid produced and change in $\mathrm{pH}$ of the medium in all the modifications was recorded.

\section{Results and Discussion}

The titrable acidity ranged from $60-76 \mathrm{mM}$ organic acids during the incubation period of 2 weeks except for $12^{\text {th }}$ day where it is maximum $(105 \mathrm{mM})$ in case of solubilisation of TCP. Results obtained from studies by Nenwani et al., 2010 also showed that highest titrable acidity is recorded after 12 days of incubation by the organism which is similar to our findings. However, there is increase in the titrable acidity during the entire period of incubation when Aspergillus niger is inoculated into the medium containing rock phosphate and maximum of $124 \mathrm{mM}$ of total acids is produced at the end of $14^{\text {th }}$ day of incubation as shown in table 1 .

A significant correlation between final $\mathrm{pH}$ value and titrable acidity has been observed (Nahas, 1996). When the fungal strain was tested to solubilise different types of phosphate in chemosynthetic medium, medium inoculated with $A$. niger showed greater reduction in $\mathrm{pH}$ (Reena et al., 2013). There was decrease in the $\mathrm{pH}$ of the medium ranging from 2-3 both in presence of TCP and rock phosphate except for $12^{\text {th }}$ day in case of TCP and $8^{\text {th }}$ day in case of rock phosphate where the $\mathrm{pH}$ is recorded as 3.74 and 3.89 respectively. The pattern of decrease in $\mathrm{pH}$ is similar in case of both TCP and rock phosphate supplemented medium by A. niger. The biomass obtained due to the proliferation of the organism during the incubation period is recorded. At the end of $14^{\text {th }}$ day, the biomass obtained from both the phosphate sources is equal $(0.174 \mathrm{~g})$ which depicts that the organism is able to grow unanimously irrespective of the phosphate sources present in the medium either TCP or rock phosphate. A strong positive correlation of 0.924 is observed between $\mathrm{pH}$ and total acids secreted by A. niger during TCP solubilisation which is 0.49 in case of rock phosphate solubilisation. This proves that organic acid production is the key mechanism for $P$ solubilisation which is accompanied by lowering of the $\mathrm{pH}$ of the medium. This fact is confirmed that production of organic acids leads to acidification of microbial cells and their surroundings resulting in the release of orthophosphate ions from the mineral phosphate (Hwangbo et al., 2003; Ben et al., 2009).

It has been observed that fungal culture produced carboxylic acid confirmed as titrable acidity. The culture supernatant obtained was spotted on whatman chromatographic paper No.1 along with the standards of organic acids. The Rf values obtained for the culture supernatant obtained from Aspergillus niger inoculated with TCP and rock phosphate were 0.9 and 0.6 respectively when compared to the standard organic acids it coincided with oxalic acid (0.91) and citric acid (0.63) respectively (Figure 1). Similarly, Illmer and Schinner, 1995 and Alam et al., 2002 also reported citric and oxalic acid to be produced by Aspergillus niger in large amounts along with small quantities of gluconic acid.

Modification of cultural and nutritional conditions also influences the organic acid production by the organism in presence of TCP and Rock phosphate. Nutritional modifications involve replacement of carbon and nitrogen sources in the medium. In presence of TCP, all the carbon sources were effectively utilised by the organism in order to produce organic acid in the medium except lactose, sorbose and inositol since much 
reduction in the $\mathrm{pH}$ of the culture filtrate is not observed in presence of these three carbon sources (Figure 2a). Similar trend is also noticed in case of organic acid secretion which is reflected from the measure of titrable acidity and maximum titrable acidity during TCP solubilisation is recorded in presence of glucose $(127 \mathrm{mM})$ followed by sucrose $(116$ $\mathrm{mM})$. However, in presence of rock phosphate; all the carbon sources were taken up by Aspergillus niger as energy source which is indicated from the amount of organic acid present in the medium except mannose. However, amount of titrable acidity is recorded higher in glucose $(45 \mathrm{mM})$ followed by maltose and sucrose ( 34 and $32 \mathrm{mM}$ ). Not much change in $\mathrm{pH}$ is observed in presence of mannose but other carbon sources showed $\mathrm{pH}$ in the range of 4.4-4.8 except fructose and raffinose as depicted from figure $2 b$.

Table.1 Periodical analysis of Biomass, organic acid and change in $\mathrm{pH}$ of culture filtrate of A. niger grown under different phosphate sources

\begin{tabular}{|c|l|c|c|c|c|c|}
\cline { 2 - 7 } \multicolumn{1}{c|}{} & \multicolumn{3}{c|}{ Tricalcium Phosphate } & \multicolumn{3}{c|}{ Rock Phosphate } \\
\hline $\begin{array}{l}\text { Incubation } \\
\text { period }\end{array}$ & $\begin{array}{l}\text { organic acid } \\
\text { production } \\
\text { in culture } \\
\text { filtrate }(\mathrm{mM})\end{array}$ & $\begin{array}{l}\text { Final } \\
\text { pH of } \\
\text { culture } \\
\text { filtrate }\end{array}$ & $\begin{array}{l}\text { Fungal biomass } \\
\text { (in g) }\end{array}$ & $\begin{array}{l}\text { organic acid } \\
\text { production } \\
\text { in culture filtrate } \\
\text { (mM) }\end{array}$ & $\begin{array}{l}\text { Final } \\
\text { pH of } \\
\text { culture } \\
\text { filtrate }\end{array}$ & $\begin{array}{l}\text { Fungal } \\
\text { biomass } \\
\text { (in g) }\end{array}$ \\
\hline Control & - & 6.8 & - & - & 7.28 & - \\
\hline Day 2 & 70 & 2.02 & 0.135 & 42 & 2.48 & 0.276 \\
\hline Day 4 & 60 & 2.12 & 0.189 & 87 & 2.78 & 0.212 \\
\hline Day 6 & 73 & 2.35 & 0.162 & 94 & 3.01 & 0.192 \\
\hline Day 8 & 76 & 2.85 & 0.192 & 98 & 3.89 & 0.18 \\
\hline Day 10 & 74 & 2.6 & 0.162 & 105 & 3.08 & 0.172 \\
\hline Day 12 & 105 & 3.74 & 0.184 & 107 & 2.84 & 0.18 \\
\hline Day 14 & 66 & 2.49 & 0.174 & 124 & 2.79 & 0.174 \\
\hline
\end{tabular}

Table.2 Effect of $\mathrm{pH}$ of the culture medium on organic acid production (titrable acidity) in presence of TCP and RP

\begin{tabular}{|r|r|l|l|l|l|l|}
\cline { 2 - 7 } \multicolumn{1}{c|}{} & \multicolumn{4}{|c|}{ Tricalcium Phosphate } & \multicolumn{3}{c|}{ Rock Phosphate } \\
\hline $\begin{array}{l}\text { Initial } \mathrm{pH} \\
\text { of the } \\
\text { medium }\end{array}$ & $\begin{array}{l}\text { organic acid } \\
\text { production } \\
\text { in culture } \\
\text { filtrate }(\mathrm{mM})\end{array}$ & $\begin{array}{l}\text { Final } \mathrm{pH} \\
\text { of } \\
\text { culture } \\
\text { filtrate }\end{array}$ & $\begin{array}{l}\text { Fungal biomass } \\
\text { (in g) }\end{array}$ & $\begin{array}{l}\text { organic acid } \\
\text { production } \\
\text { in culture filtrate } \\
\text { (mM) }\end{array}$ & $\begin{array}{l}\text { Final } \mathrm{pH} \\
\text { of } \\
\text { culture } \\
\text { filtrate }\end{array}$ & $\begin{array}{l}\text { Fungal } \\
\text { biomass } \\
\text { (in } \mathrm{g})\end{array}$ \\
\hline 5 & $53 \pm 1$ & $3.68 \pm 0.021$ & $0.187 \pm 0.003$ & $36 \pm 4$ & $4.25 \pm 0.23$ & $0.097 \pm 0.012$ \\
\hline 6 & $42 \pm 3.2$ & $4.14 \pm 0.16$ & $0.186 \pm 0.016$ & $37 \pm 2.3$ & $4.51 \pm 0.23$ & $0.086 \pm 0.011$ \\
\hline 7 & $38 \pm 2.1$ & $4.12 \pm 0.26$ & $0.191 \pm 0.010$ & $25 \pm 3.1$ & $4.20 \pm 0.09$ & $0.081 \pm 0.005$ \\
\hline 8 & $37 \pm 0$ & $3.97 \pm 0.03$ & $0.183 \pm 0.017$ & $19 \pm 1.53$ & $3.99 \pm 0.16$ & $0.089 \pm 0.012$ \\
\hline 9 & $40 \pm 2$ & $4.98 \pm 0.074$ & $0.16 \pm 0.019$ & $19 \pm 1.73$ & $4.51 \pm 0.19$ & $0.093 \pm 0.017$ \\
\hline
\end{tabular}


Table.3 Effect of Temperature of the culture medium on organic acid production (titrable acidity) in presence of TCP and RP

\begin{tabular}{|c|c|c|c|c|c|c|}
\cline { 2 - 7 } \multicolumn{1}{c|}{} & \multicolumn{3}{c|}{ Tricalcium Phosphate } & \multicolumn{3}{c|}{ Rock Phosphate } \\
\hline $\begin{array}{c}\text { Temperature } \\
\left({ }^{\circ} \mathrm{C}\right)\end{array}$ & $\begin{array}{c}\text { organic acid } \\
\text { production in culture } \\
\text { filtrate }(\mathrm{mM})\end{array}$ & $\begin{array}{c}\text { Final pH of } \\
\text { culture } \\
\text { filtrate }\end{array}$ & $\begin{array}{c}\text { Fungal } \\
\text { biomass (in g) }\end{array}$ & $\begin{array}{c}\text { organic acid } \\
\text { production in } \\
\text { culture filtrate }(\mathrm{mM})\end{array}$ & $\begin{array}{c}\text { Final } \mathrm{pH} \\
\text { of culture } \\
\text { filtrate }\end{array}$ & $\begin{array}{c}\text { Fungal } \\
\text { biomass (in g) }\end{array}$ \\
\hline 20 & $41 \pm 6.6$ & $3.64 \pm 0.12$ & $0.169 \pm 0.018$ & $36 \pm 1.73$ & $4.41 \pm 0.05$ & $0.089 \pm 0.005$ \\
\hline 25 & $47 \pm 3.8$ & $3.44 \pm 0.015$ & $0.201 \pm 0.019$ & $33 \pm 4.04$ & $4.66 \pm 0.12$ & $0.091 \pm 0.003$ \\
\hline 30 & $43 \pm 3.5$ & $3.76 \pm 0.123$ & $0.174 \pm 0.017$ & $33 \pm 1.15$ & $4.61 \pm 0.07$ & $0.100 \pm 0.012$ \\
\hline 35 & $46 \pm 2.5$ & $3.96 \pm 0.11$ & $0.177 \pm 0.014$ & $24 \pm 2.08$ & $4.31 \pm 0.31$ & $0.102 \pm 0.009$ \\
\hline 40 & $45 \pm 2$ & $3.97 \pm 0.114$ & $0.163 \pm 0.006$ & $22 \pm 1.15$ & $4.56 \pm 0.035$ & $0.086 \pm 0.009$ \\
\hline
\end{tabular}

Fig.1 Qualitative analysis of organic acids produced by Aspergillus nigerunder different phosphate sources (Rf values)

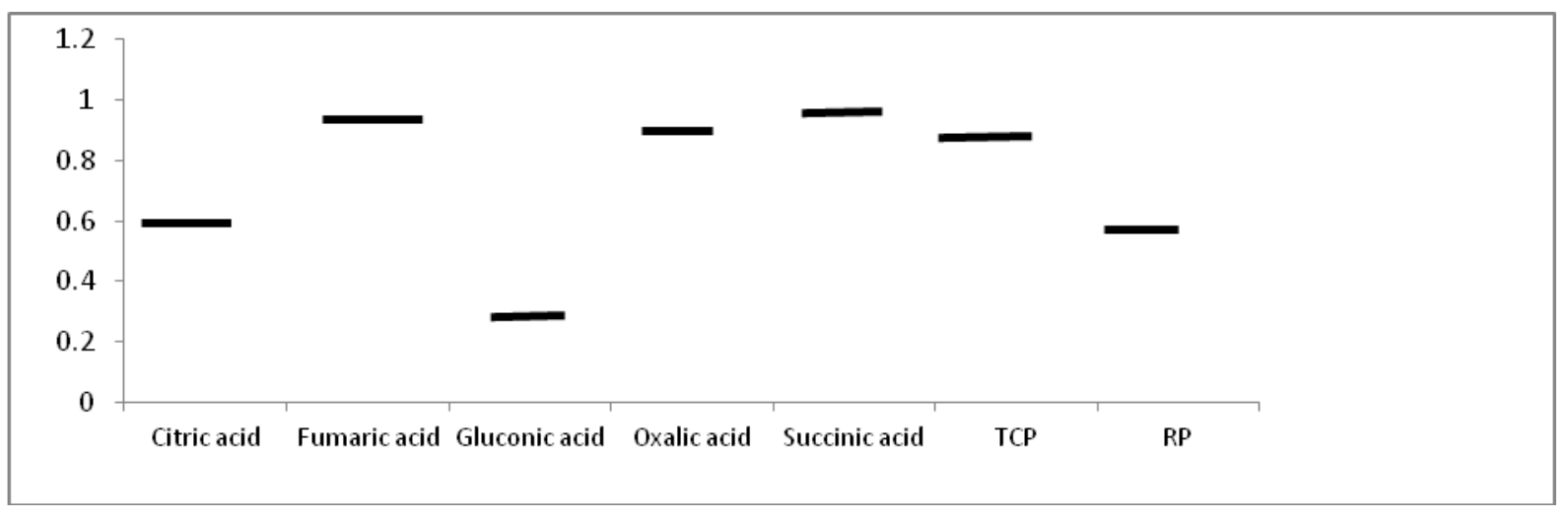

Fig.2a Organic acid secretion in form of titrable acidity in presence of TCP and RP supplemented with different carbon sources

\section{Amount of organic acid secreted (in $\mathrm{mM}$ )}

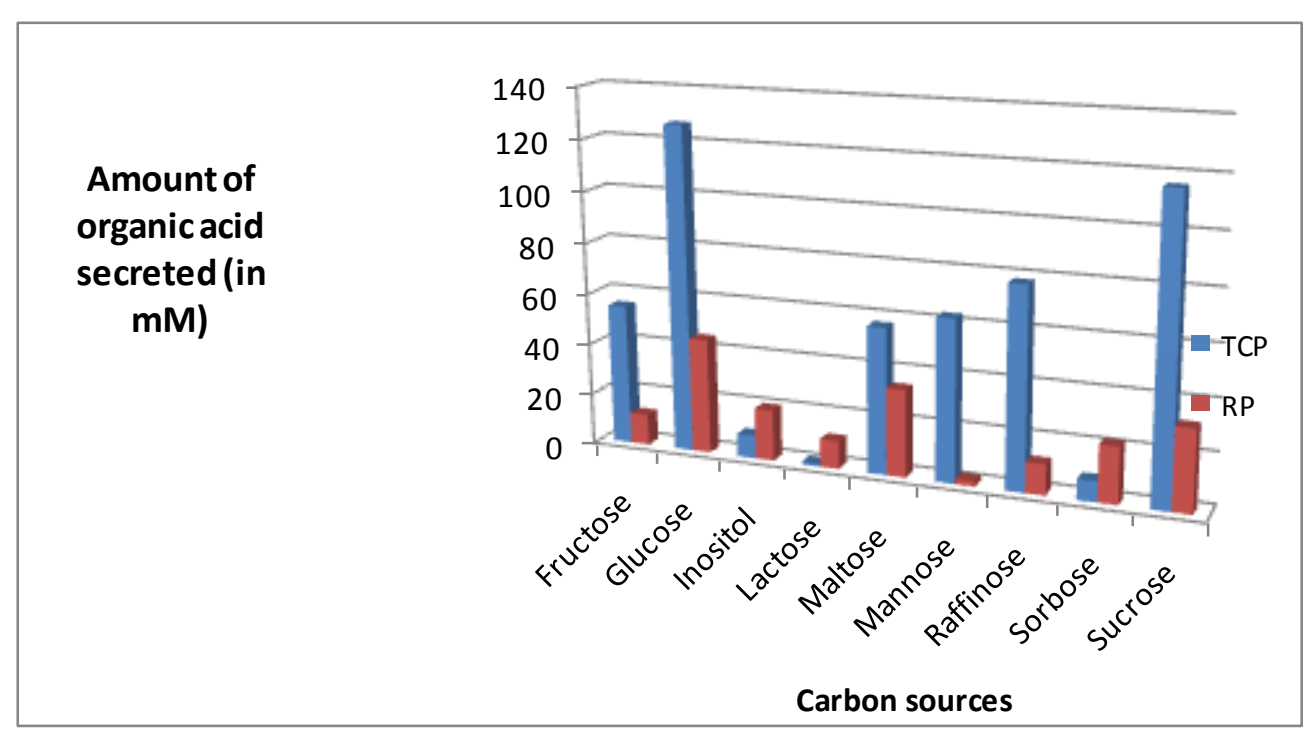


Fig.2b pH change during organic acid production supplemented with different carbon sources in presence of TCP and RP

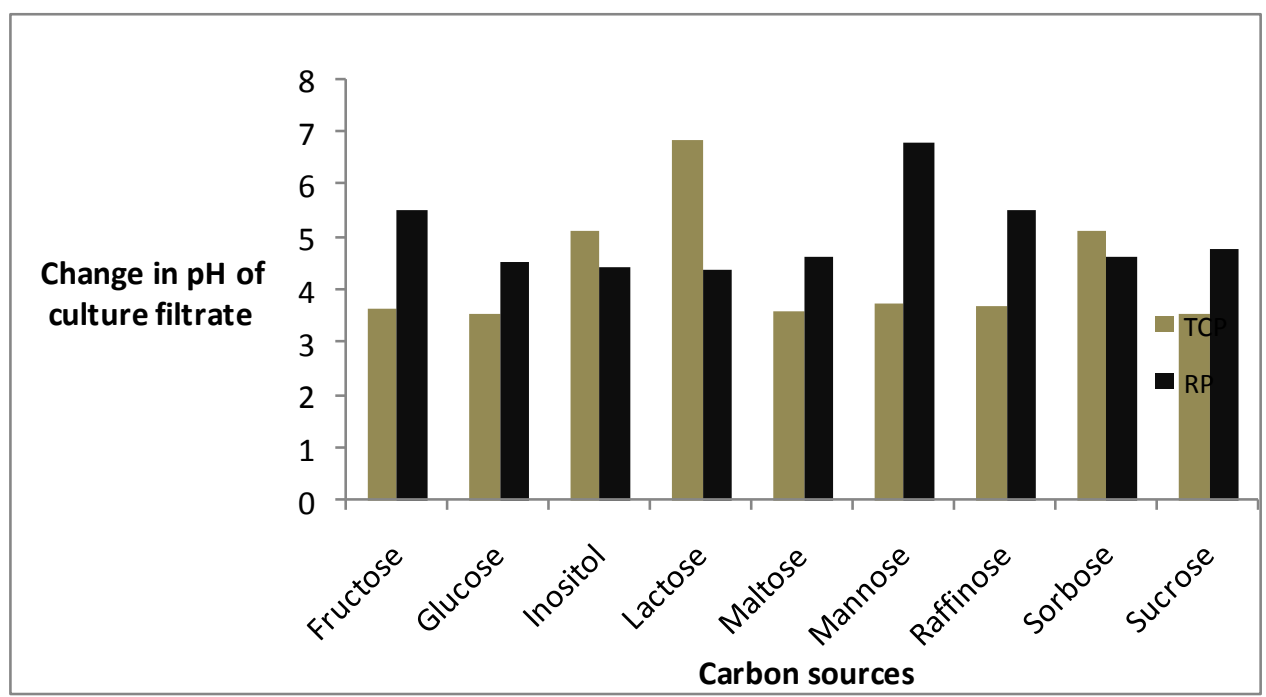

Fig.3a Organic acid secretion in form of titrable acidity in presence of TCP and RP supplemented with different nitrogen sources

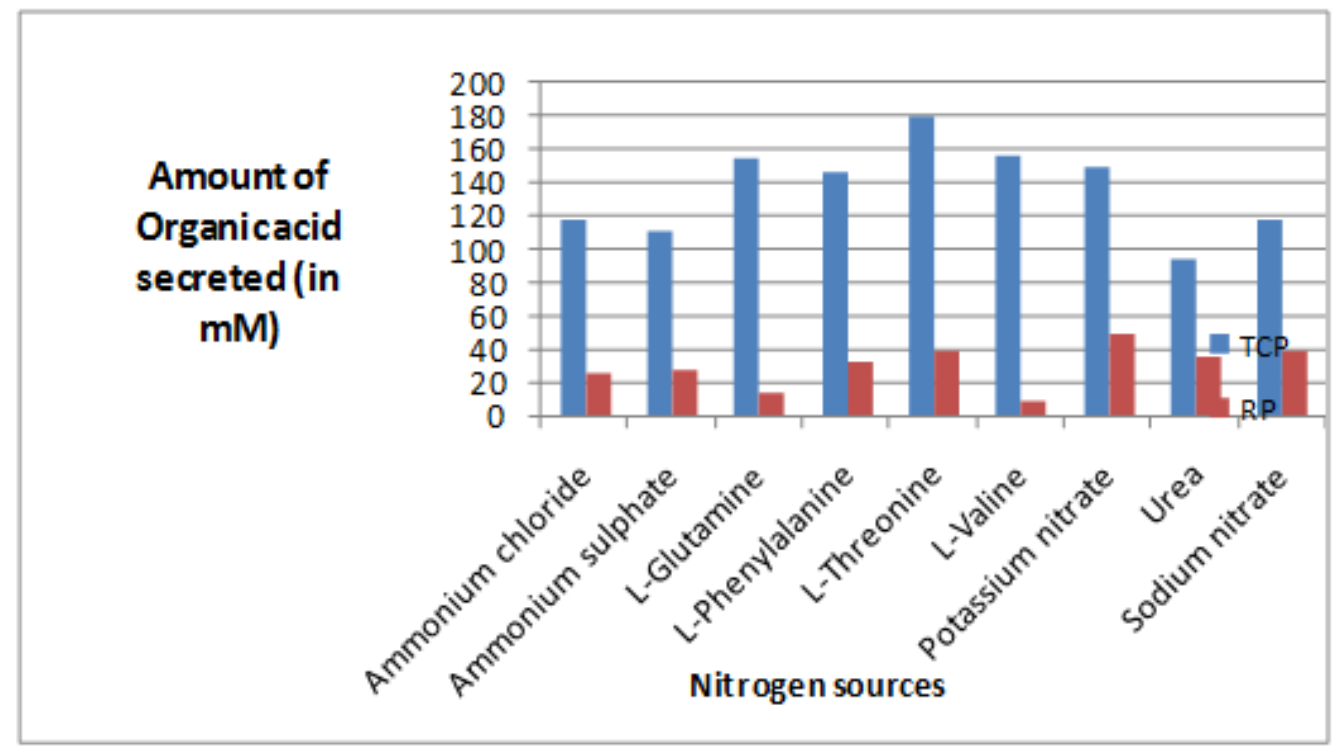


Fig.3b pH change during organic acid production supplemented with different nitrogen sources in presence of TCP and RP

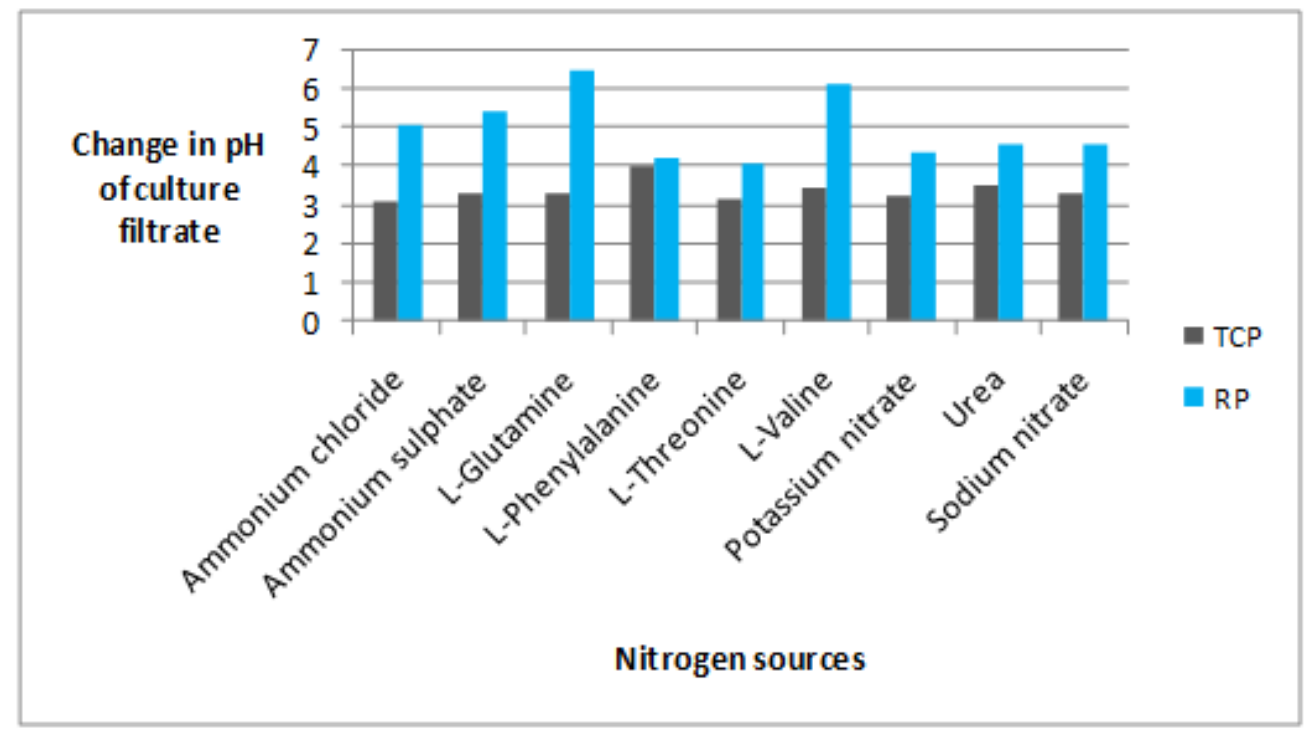

For nitrogen sources, all the nitrogenous compounds and amino acids were suitably consumed by the organism for its metabolic activity since the amount of T.A. was higher in presence of TCP for all the nitrogen containing compounds with glucose as carbon source in the range of $94-179 \mathrm{mM}$ suggesting that modification enhanced the organic acid producing ability of $A$. niger as shown in figure 3a. Maximum titrable acidity was recorded in medium modified with amino acid L-valine (179 $\mathrm{mM})$.

Similar observation was noted for $\mathrm{pH}$ change in the culture filtrate with Final $\mathrm{pH}$ ranging from 3.12-4.03 in presence of TCP and with rock phosphate supplementation in the medium in presence of different nitrogen sources it was noticed that there is greater variation in the $\mathrm{pH}$ of the culture filtrate with wider $\mathrm{pH}$ ranging from 4.13-6.53 (Figure 3b). The titrable acidity estimated is the amount of organic acid secreted into the medium was found to be lower than that of TCP supplemented medium and highest T.A. was indicated in presence of potassium nitrate (49 $\mathrm{mM})$ followed by sodium nitrate $(39 \mathrm{mM})$.
Upon modification of the initial $\mathrm{pH}$ of the medium, the change in the final $\mathrm{pH}$ of the medium in presence of TCP as $\mathrm{P}$ source varied from $3.68(\mathrm{pH} \mathrm{5)}$ to $4.98(\mathrm{pH} \mathrm{9)}$ and amount of titrable acidity also ranged from 37-53 mM under such conditions. The $\mathrm{pH}$ change at different incubation temperatures also ranged from $3.44\left(25^{\circ} \mathrm{C}\right)$ to $3.97\left(40^{\circ} \mathrm{C}\right)$ which suggested that organic acid is secreted into medium by lowering of $\mathrm{pH}$ and at ambient temperature of incubation. However, the amount of acid release at different temperature range is almost same $(41-47 \mathrm{mM})$ as much difference in their values is not observed. In presence of rock phosphate, the $\mathrm{pH}$ change is not much significant because the final $\mathrm{pH}$ for all modifications is in the range of 4-4.5. Similar findings were also recorded in case of various incubation temperatures for rock phosphate also as the final $\mathrm{pH}$ ranged from 4.3-4.7. The amount of titrable acidity measured at different $\mathrm{pH}$ and temperature conditions showed that it is more in case of initial $\mathrm{pH} 6$ and temperature $20^{\circ} \mathrm{C}$ which is $37 \pm 2.3 \mathrm{mM}$ and $36 \pm 1.73 \mathrm{mM}$ respectively (Tables 2 and 3). 
Overall, it can be concluded that cultural conditions of different range of $\mathrm{pH}$ and incubation temperature do not play an important role in organic acid secretion by the fungi. Hence, the organic acid secretion is mostly influenced by the nutritional sources present in the medium which regulates the metabolic pathway of the organism.

Although organic acid production influences the solubilisation process as determined from $\mathrm{pH}$ and titrable acidity in the present in vitro study but in vivo effect on the plant growth can only justify the potential of the strain used in this experiment.

\section{Acknowledgement}

The financial assistance obtained through INSPIRE programme (No. DST/INSPIRE Fellowship/2013/506) DST, Govt. of India is gratefully acknowledged.

\section{References}

Alam, S., Khalil, S., Ayub, N. and Rashid, M. 2002. In vitro solubilisation of Inorganic phosphate by Phosphate Solubilising Micro-Organisms (PSM) from maize rhizosphere. International journal of Agriculture and biology. 4(4):454-58.

Barroso, C.B., Nahas, E. 2005. The status of soil phosphate fractions and the ability of fungi to dissolve hardly soluble phosphates. Appl. Soil Ecol. 29, 73-83.

Ben Farhat, M., Farhat, A., Bejar, W., Kammoun, R., Bouchaala, K., Bejar, S., Chouayekh, H. 2009. Characterization of the mineral phosphate solubilizing activity of Serratia marcescens CTM 50650 isolated from the phosphate mine of Gafsa. Arch Microbiol. 191, 815824.

Bhattacharya, P., Jain, RK. 2000. Phosphorous solubilizing biofertilizers in the whirl pool of rock phosphate challenges and opportunities. Fert News. 45, 45-52.

Bolan, N.S., Mahimairaja, S., Baskaran, S. 1994. Influence of low molecularweight organic acids on the solubilization of phosphates. Biol. Fertil. Soils, 18, 311-319.

Cunningham, J.E., Kuiack, C. 1992. Production of citric and oxalic acids and solubilization of calcium phosphate by Penicillium bilaii. Appl. Environ. Microbiol. 58, 1451-1458.

Di Simine, C.D., Sayer, J.A.; Gadd, G.M. 1998. Solubilization of zinc phosphate by a strain of Pseudomonas fluorescens isolated from a forest soil. Biol. Fertil. Soils, 28, 87-94.

Goldstein, A.H., 1995. Recent progress in understanding the molecular genetics and biochemistry of calcium phosphate solubilization by Gram negative bacteria. BiolAgricHortic 12:185-193.

Gupta, J.K., Heding, L.G.; Jorgensen, O.B. 1976. Effect of sugars, hydrogen ion concentration and ammonium nitrate on the formation of citric acid by Aspergillus niger. ActaMicrobiol. Acad. Sci. Hun.,23, 63-67.

Gyaneshwar, P., Kumar, N., Parekh, L.J., Poole, P.S. 2002. Role of soil microorganisms in improving $\mathrm{P}$ nutrition of plants. Plant Soil 245: 8393.

Hwangbo, H., Park, R.D., Kim, Y.W., Rim, Y.S., Park, K.H., Kim, T.H., Suh, J.S., Kim, K.Y. 2003. 2-ketogluconic acid production and phosphate solubilization by Enterobacter intermedium. Curr. Microbiol. 47: 87-92.

Illmer, P., and Schinner, F. 1995. Solubilization of inorganic calcium phosphate - solubilization mechanisms. Soil Biol. Biochem. 27: 257-263.

Illmer, P., Barbato, A., Schinner, F. 1995. Solubilization of hardly solubleAlPO4 
with P-solubilizing microorganisms. Soil Biol. Biochem. 27: 265-270.

Jones, D.L., 1998. Organic acids in the rhizosphere - a critical review. PlantSoil 205:25-44.

Kang, S.C., Ha C.G., Lee T.G. and. Maheshwari D.K 2002. Solubilization of insoluble inorganic phosphates by a soil inhabiting fungus Fomitopsis sp PS 102. Curr. Sci., 82, 439-441.

Mahidi, S.S., Hassan, G., Hussain, A., Faisalur-Rasool. 2011. Phosphorus availability issue. Its fixation and role of phosphate solubilizing bacteria in phosphate solubilization case study. Res J AgricSci. 2:174-179.

Nahas, E., Banzatto, D.A., Assis, L.C. 1990. Fluorapatite solubilization by Aspergillus niger in vinasse medium. Soil Biol.Biochem. 22: 1097-110.

Nenwani, V., Doshi, P., Saha, T., Rajkumar, S. 2010. Isolation and characterization of a fungal isolate for phosphate solubilization and plant growth promoting activity. Journal of Yeast and Fungal research. 1(1): 9-14.

Reyes, I., Bernier, L.; Simard, R.R.; Antoun, H. 1999. Effect of nitrogen source on the solubilization of different inorganic phosphates by an isolate of Penicillium rugulosum and two UV-induced mutants. FEMS Microbiol. Ecol., 28, 281-290.

Rodríguez, H., and Fraga, R. 1999. Phosphate solubilizing bacteria and their role in plant growth promotion. Biotechnol. Adv. 17, 319-339.

Scervino, J.M., Mesa, M.P., Monica, I.D., Recchi, M., Moreno, N.S., Godea, A. 2010 Soil fungal isolates produce different organic acid patterns involved in phosphate salts solubilization. BiolFertil Soils. 46, 755-763.

Strobel, B.W., 2001. Influence of vegetation on low-molecular-weight carboxylic acids in soil solution: A review. Geoderma 99, 169-198.

Vassilev, N., Fenice, M.I., Federici, F. 2004. Rock phosphate solubilisation with gluconic acid produced by immobilized Penicillium variabile P16. Biotechnol Tech 10, 585-588.

Vazquez, P., Holguin, G., Puente, M.E., Lopez-Cortes, A., Bashan, Y. 2000Phosphate- solubilizing microorganisms associated with the rhizosphere of Mangroves in a semiarid Coastal lagoon. BiolFertil Soils. 30, 460-468.

Venketeshwarlu, B., Rao, A.V., Raina, P., Ahmad, N. 1984. Evaluation of phosphorus solubilisation by microorganisms isolated from aridisols. J. Indian. Soc. Soil Sci. 32, 273-77.

Whitelaw, M.A., Harden, T.J., Helyar, K.R. 1999. Phosphate solubilization in solution culture by the soil fungus Penicillium radicum. Soil Biol. Biochem. 32, 655-665.

\section{How to cite this article:}

Hruda Ranjan Sahoo and Nibha Gupta. 2017. Qualitative and Quantitative Analysis of Organic Acid Production Influenced by Phosphate Sources under Submerged Culture of Aspergillus niger a Phosphate Solubilising Fungi. Int.J.Curr.Microbiol.App.Sci. 6(9): 3358-3366. doi: https://doi.org/10.20546/ijcmas.2017.609.414 